\begin{tabular}{|l|l|l||}
\hline \multicolumn{2}{|c|}{ PublisherInfo } \\
\hline \hline PublisherName & $:$ & BioMed Central \\
\hline \hline PublisherLocation & $:$ & London \\
\hline \hline PublisherImprintName & $:$ & BioMed Central \\
\hline \hline
\end{tabular}

\title{
Mutations in CIASIgene cause familial cold autoinflammatory syndrome and Muckle-Wells syndrome
}

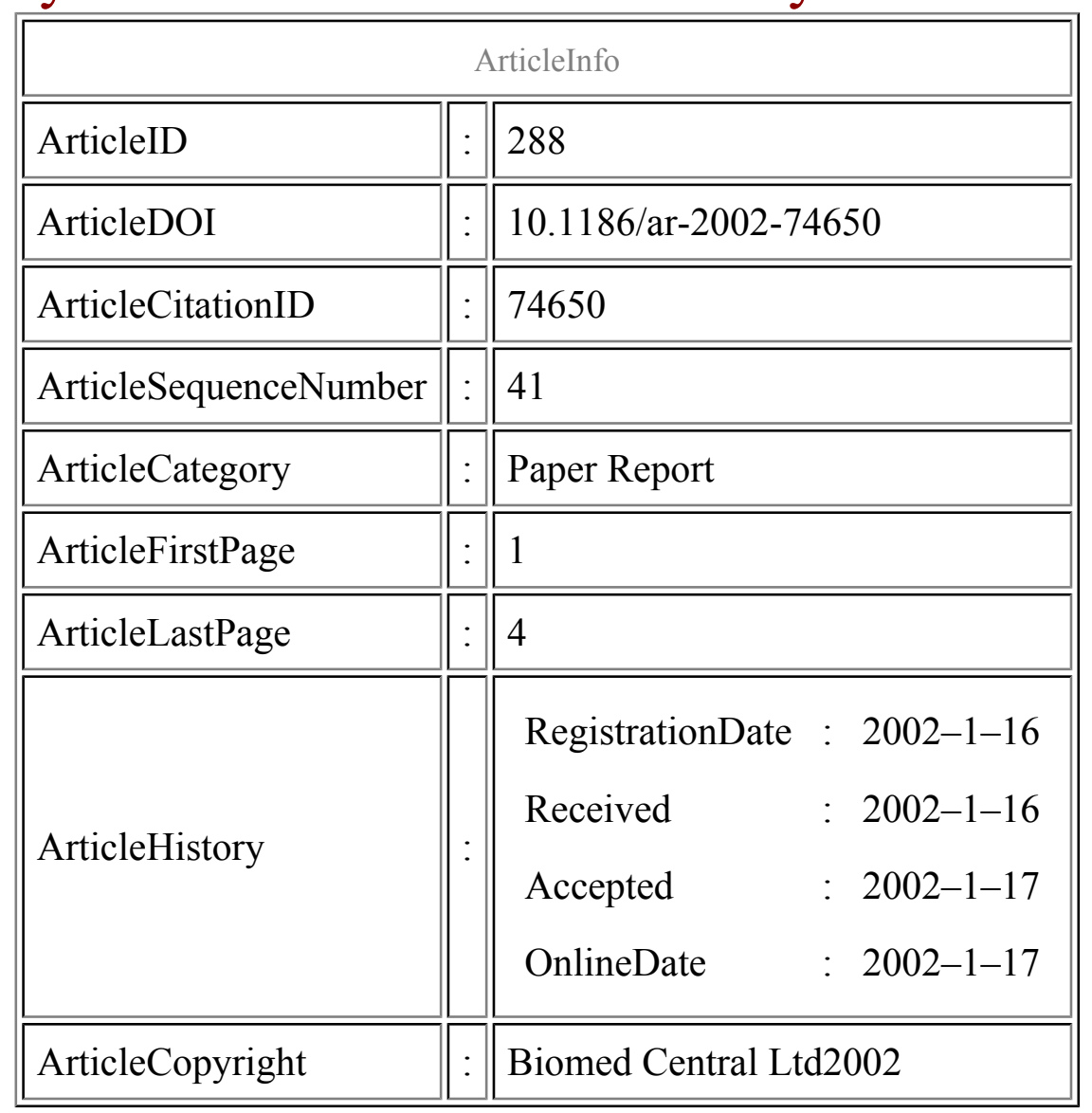




\begin{tabular}{|l|l|l||}
\hline ArticleGrants & $:$ & \\
\hline \hline ArticleContext & $:$ & 130754411 \\
\hline
\end{tabular}

Roberto Caricchio, ${ }^{\text {Aff1 }}$

Aff1 University of Pennsylvania, PA, USA

\section{Keywords}

CARD, FCAS, FMF, MWS, Pyrin

\section{Context}

Autoinflammatory syndromes are rare conditions defined by recurrent inflammatory symptoms. Phenotype varies among these diseases; however a subgroup is characterized by intermittent attacks of fever associated with rash and arthralgia. These diseases include familial mediterranean fever (FMF), hyper-IgD syndrome (HIDS), TNF receptor-associated periodic syndrome (TRAPS), familial cold autoinflammatory syndrome (FCAS), and Muckle-Wells syndrome (MWS). Mutations in the $M E F V$ gene in FMF, mevalonate kinase in HIDS, and TNFR1 in TRAPS have been previously identified. In this paper the authors described a new gene (CIAS1) in which mutations are found in FCAS and MWS.

\section{Significant findings}

Initial studies identified a locus for FCAS on chromosome 1q44. With expressed sequence tag (EST) mapping of this region, the authors identified missense mutations in exon 3 of the CIAS1 gene. Three families with FCAS and one with MWS were studied. Each family showed a unique missense mutation. These mutations were not found in unaffected members of the families or in controls. CIAS is expressed mainly, at a low level, in peripheral blood leukocytes; an expression pattern similar to the gene involved in FMF ( $M E F V)$. Moreover, analysis of genomic exon sequence revealed alternative splicing of exons 4-8. Analysis of the predicted protein (Cryopyrin) encoded by the first splice form of CIASlidentifield an N-terminal pyrin domain, a central NACHT domain, and a C-terminal LRR domain. The structural characteristics suggest that the protein is a signaling protein involved in the regulation of inflammation and apoptosis. 


\section{Comments}

FCAS and MWS are autosomal-dominant inflammatory diseases with a similar phenotype, except that the symptoms in MWS are not triggered by cold exposure and that patients with MWS develop progressive nerve deafness, and multiorgan AA-type amyloidosis. Strikingly, the gene responsible for both diseases is CIAS1, although the missense mutations are unique in each syndrome. Therefore it is possible that different mutations determine the outcome of the phenotype, which may also be modulated by different genetic backgrounds and of environmental factors (see Additional information).

Interestingly, cryopyrin shares homology with a CARD-like pyrin domain, and with NALP1, NALP2, Nod1 (CARD4), Nod2 (CARD15) and ASC, all of which are recently identified proteins with apoptosis and innate immunity functions. The fact that diverse proteins, which are mutated in different autoinflammatory hereditary diseases, share apoptosis and inflammatory functions has shed new light on the pathogenesis of these syndromes. In addition these observations will likely give further insight into the fine tuning of apoptosis and inflammation.

\section{Methods}

Gene mapping and cloning, missense mutation analysis, exon prediction programs, northern analysis.

\section{Additional information}

Miceli-Richard C, Lesage S, Rybojad M, Prieur AM, Manouvrier-Hanu S, Hafner R, Chamaillard M, Zouali H, Thomas G, Hugot JP: CARD15 mutations in Blau syndrome. Nat Genet 2001, 29: 19-20

Ogura Y, Bonen DK, Inohara N, Nicolae DL, Chen FF, Ramos R, Britton H, Moran T, Karaliuskas R, Duerr RH, Achkar JP, Brant SR, Bayless TM, Kirschner BS, Hanauer SB, Nunez G, Cho JH: A frameshift mutation in NOD2 associated with susceptibility to Crohn's disease. Nature 2001, 411: 603-606

Hugot JP, Chamaillard M, Zouali H, Lesage S, Cezard JP, Belaiche J, Almer S, Tysk C, O'Morain CA, Gassull M, Binder V, Finkel Y, Cortot A, Modigliani R, Laurent-Puig P, Gower-Rousseau C, Macry J, Colombel JF, Sahbatou M, Thomas G: Association of NOD2 leucine-rich repeat variants with susceptibility to Crohn's disease. Nature 2001, 411: 599-603 


\section{References}

1. Hoffman HM, Mueller JL, Broide DH, Wanderer AA, Kolodner RD: Mutation of a new gene encoding a putative pyrin-like protein causes familial cold autoinflammatory syndrome and MuckleWells syndrome. Nat Genet. 2001, 29: 301-305.

This PDF file was created after publication. 